Tér és Társadalom 11. évf. 1997/4. 105-117. p.

Tér és Társadalom

1997 4: $105-130$

GYORS TÉNYKÉP

\title{
MÜSZAKI VERSENYKÉPESSÉG AZ ÁTMENETI GAZDASÁGBAN: KÜLFÖLDI ÉS HAZAI VÁLLALATOK A MAGYAR IPARBAN
}

(Technological Competitiveness in the Transition Period: Foreign and Domestic Industrial Investments in Hungary)

\section{BARTA GYÖRGYI}

Az államszocializmus egyik öröksége a kelet-európai országok jelentős müszaki lemaradása a fejlett országoktól. A technikai lemaradás oka jól ismert: a verseny hiánya, a nagyvállalatok monopol-helyzete, a hiánygazdaság egyaránt hozzájárult ahhoz, hogy nem alakult ki az állandó késztetés a termékek, technológiák megújítására, az innovációra.

Mivel az erőforrások ára alacsony volt és egyáltalán nem felelt meg a világpiaci arányoknak, nem alakult ki az energiával, a nyersanyagokkal, és a humán erőforrásokkal való takarékoskodás kényszere. 1979-ben, például, 1.000 dollárnyi GDP elöállításához Kelet-Európa hat országában átlagosan 1.362 szénegységre, Nagy-Britanniában 820, Nyugat-Németországban 565 szénegységre volt szükség. (Kornai 1993)

$\mathrm{Az}$ említett okok arra is választ adnak, hogy a technológiai transzfer miért volt olyan gyenge az államszocialista országokban. Ez jóformán hiányzott a fejlettebb és elmaradottabb szektorok között (pl. a hadiipar és a civil gazdaság ágazatai között), de igen gyenge maradt a termelö ágazatok és a $\mathrm{K}+\mathrm{F}$ tevékenység között is. De sem a KGST tagországai, sem a hazai vállalatok között nem alakult ki számottevố technológiai transzfer, mivel a kapcsolatokat inkább a munkamegosztás és kevésbé a verseny formálta. Mindemellett a KGST-tagországok mindvégig megörizték gazdaságaik önellátó jellegét. A KGST-n belül a kereskedelem jobbára bilateriális jellegủ maradt, fóként a Szovjetunióból származó energia- és nyersanyagimportra, és a feldolgozott ipari és mezögazdasági termékek exportjára épült, valamint korlátozott mértékú és hasonló struktúrájú külkereskedelemre a többi tagország között.

A KGST összeomlásával és a nagyvállalatok dezintegrációjával a kialakult külsö és belsö kapcsolatok teljesen szétestek. A piacgazdaság kibontakozása azonban nem vezetett automatikusan a $\mathrm{K}+\mathrm{F}$ tevékenység megújulására, illetve az innovációorientált vállalati magatartás azonnali megjelenésére. Egyelöre az újonnan alapított, vagy az átszervezett vállalatok rugalmas alkalmazkodó képessége utal a vállalati mentalitás megváltozására. 
E tanulmány egyrészt a külföldi múködőtőke-befektetések szerepét és hatásait vizsgálja a magyar gazdaság müszaki fejlödésének felgyorsulásában, másrészt a hazai és a külfơldi vállalatok között formálódó kapcsolat-hálózatok kialakulásáról ad számot. Bemutatjuk, hogy a magyar vállalatoknak milyen típusai alakultak ki aszerint, hogy hogyan képesek integrálódni a világgazdaságba. A hazai gazdaság integrációs folyamatai részben az államszocialista gazdaságban létrejött szervezeti, kooperációs és személyi kapcsolatok fennmaradására, vagy megújulására, részben új kapcsolatokra épülnek, egyre szélesebb csatornákat nyitva a technológiai transzfer számára. Az utolsó fejezetben röviden foglalkozunk a $\mathrm{K}+\mathrm{F}$ tevékenység visszaesésével, és kedvezőtlen következményeivel.

\section{Külföldi és hazai iparvállalatok technológiai stratégiái}

Elfogadjuk egyrészt azt a nézetet (Tamás 1995), hogy "az ágazati környezet és az adott technológiák mellett az eltérő vállalati stratégiai felfogások azok, amelyek az adott szervezet innovációs profilját leginkább meg fogják határozni". Véleményünk szerint a külföldi és hazai tulajdonú vállalatok stratégiái élesen elkülönülnek egymástól.

\section{A külföldi tulajdonú vállalatok stratégiái}

A befektető számára talán az új piac megszerzése a legfontosabb motiváció. Ez történhet úgy, hogy a beruházó müködö vállalatokat vásárol, vagy új vállalatokat alapít a fogadó országban, vagy új, korábban nem mủvelt ágazatot honosit meg (tipikus példa Magyarországon a személygépkocsi gyártás). Romboló hatású lehet a fogadó ország gazdasága számára, ha az új tulajdonos hamarosan bezárja a privatizáció révén létesített vállalkozását, és/vagy saját, kủlfờldön gyártott termékeivel látja el a fogadó ország piacát. (Ilyen példákat is lehet találni a magyar gyakorlatban, például a növényolaj iparban, vagy a cukoriparban. Sőt, a jól kiépített kiskereskedelmi hálózatok eladása külföldi tulajdonosnak sem volt a legszerencsésebb üzletnek nevezhetó.)

A külfơldi beruházó gyakran a kedvezőbb termelési feltételeket keresi a fogadó országokban. Ilyen előnyöket jelentenek például:

- A viszonylag olcsó és képzett munkaerőforrás (bár vannak Magyarországon is hiányszakmák, például a menedzsment, a logisztika és a marketing területén);

- A magyar munkaerő tanulékonysága és hajlandósága képzettségi szintjének emelésére;

- A tönkrement magyar tulajdonú vállalatok viszonylag alacsony eladási ára;

- Az elfogadhatóan kiépített infrastruktúra az ország egyes részein (különösen a fơvárosban és az Északnyugat-Dunántúlon);

- Az átlátható jogi környezet, az üzletbarát atmoszféra;

- A stabil politikai helyzet, stb. 
Magyarországon összeszerelő és végtermék gyártó vállalatokat létesített jónéhảny befektető (az Opel és a Suzuki a személygépkocsi gyărtásban, a General Electric a fényforrásgyártásban, az Elektrolux a hủtőgépgyártásban stb.). Az alvállalkozói lehetőségek nem elég bőségesek, de nỏvekvő számúak (például a Ford, vagy az Audi esetében). A bérmunka is jelentős maradt, elsősorban a cipógyártásban, a textiliparban és a az elektronikai iparban. A beruházások gyakran a fogyasztói piac alsó, bövululő szegmensét célozzák meg az olcsóbb, egyszerú termékek gyártásával. (Nem ritkán a fejlett országok termelésében már az életciklusuk végén járó termékek termelését szervezik meg Magyarországon. Például az itt összeszerelt autók tőbbsége az olcsóbb, kisautó kategóriába tartozik, amelyeket az anyaországokban már nem gyártanak). De az is előfordul, hogy a befektető a saját országának kedvezőtlenre forduló gazdasági környezetéből "menekủl elöre", amikor kúlfơldön próbálkozik. Ez jellemzi például a dél-koreai befektetéseket külfơldön. (The Economist, May 17, July 12, August 23 1997).

Általában elmondható, hogy egyrészt a külfóldi beruházás legfőbb ösztönzője Magyarországon a piacszerzés, és a kedvezöbb termelési körülmények. Másrészt, igen nehéz élesen szétválasztani e két motiváló okot egymástól, igen gyakran együtt jelentkeznek.

A külföldi befektetések motivációira utal a megtermelt profit felhasználásának módja, vagyis, hogy a profitot újra beruházzák-e a fogadó országban, vagy kivonják onnan. Bár a kủlfơldi müködőtőke-befektetésekről elég bőségesen állnak rendelkezésre információk, arra nehéz választ kapni, hogy mi tơrténik a profittal. Egy 1995 évi Nemzeti Bank jelentésre hivatkozunk, amely azt mutatta, hogy viszonylag alacsony volt a profit repatriálása eddig. "1994 végéig körülbelül 100 M Ft profitot utaltak haza évente, ez $142 \mathrm{M}$ Ft-ra rúgott 1995 szeptemberéig. Nehéz megbecsülni a töke áthelyezése (transzfer, tỏkefolyamatok, menedzseri szerzōdések, marketing szerződések, stb.) révén történõ tökekivonás értékét. Mivel a makrogazdasági körülmények, illetve a beruházási klíma egyre kedvezöbben alakul, jelenleg nem kell számottevó tôkekivonástól tartani." (Csáki-Sas-Szalavet 1996)

A külföldi tôkének a müszaki haladásra, a technológiai színvonal emelésére gyakorolt hatása eléggé ellentmondásos, de tőbbnyire pozitív. A külfơldi mủkődőtőke alapvetően hozzájárul a müszaki színvonal javulásához, de ez ritkán jelenti a high-tech meghonosítását, sokkal inkább a korábbi magyarországi technológiai színvonalnál valamelyest korszerúbb technika bevezetését.

Jellegzetes különbség rajzolódik ki a zöldmezós és a barnamezős (lásd alább) befektetések technológiai színvonalában és fejlesztésében. A nagybefektetők közuil azok, amelyek zőldmezős beruházásokat valósítoitak meg általában élenjáró technológiát alkalmaztak, szigorú minőségi és termelékenységi követelményeket támasztottak."

A barnamezős (brownfield) beruházások keretében - amelyek az állami vállalatok privatizációja folyamán kerültek külfỏldi tulajdonba - már jellemzỏen nem az élvonalbeli, de a korábbinál tőbbnyire korszerúbb technológiát honosítottak meg. Tơbb élelmiszeripari vállalat, de különösen a hútőipar erre a példa, bár akad pozitív ellenpélda is, mint az osztrák-magyar vegyes tulajdonba került Graboplast, amely világszinvonalú termékeket gyárt. (Grayson-Bodily 1996) 
A nagyobbrészt tókeemelés révén megvalósuló közepes nagyságú külföldi vállalatok technológiai színvonala is inkább követö jellegü, de még ezek is segítenek csőkkenteni a magyar ipar jelentős technológiai lemaradását. ${ }^{2}$

\section{A hazai vállalatok technológiai stratégiái}

Empirikus vizsgálataink tapasztalatai szerint (amelyekre hivatkozni fogunk a késöbbiekben) mind a hazai, mind a külfôldi tulajdonú vállalatokon belül is különböző vállalati alosztályokat lehet elkülöníteni. Tanulmányunk korlátozott terjedelme miatt itt csak a hazai vállalatokat igyekszünk típusokba sorolni, amelyek a következők:

- A helyi piacra összpontosító vállalatok;

- A regionális hálózatokba kapcsolódott vállalatok: ipari körzetek;

- A high-tech hálózatokba kapcsolódott cégek: technológiai ơvezetek;

- Az új munkamegosztás első vonalába bekapcsolódott magyar cégek.

\section{A helyi piacra összpontositó vállalatok}

1990 és 1996 között több mint kétszeresére növekedett a gazdasági szervezetek száma. (1996-ban 750 ezer egyéni vállalkozást, 158 ezer jogi személyiség nélküli és 126 ezer jogi személyiségủ társas vállalkozást tartottak számon Magyarországon.) Az első két vállalkozási forma esetében nincs szükség jelentős induló tökére. A jelentősebb vállalkozások, kơztük a kullföldi alapítású vállalatok a jogi személyiségü kategóriába tartoznak. A szervezetek tőbbsége többnyire kényszerből vállalta az onálló egzisztencia megteremtését. Az e körbe tartozó vállalkozások kisméretủek, a jogi személyiség nélkulli társas vállalkozások $99 \%$-ában a foglalkoztatottak száma nem haladja meg a 10 föt. E vállalkozók többsége önfoglalkoztatónak tekinthetö, akik nem képesek tőkefelhalmozásra, a termelés, ill. a vállalkozásuk növelésére. Ök inkább túlélők, akik jobbára felélik jövedelmeiket és vagyonukat. Ez a kategória elsősorban a munkahely-hiányos, fejletlen gazdaságokban képvisel jelentös arányokat, Magyarországon az aktív kereső́k 22\%-a sorolható ide. Hasonló adatokkal jellemezhetỏ Írország, Olaszország, Spanyolország és Portugália. Görögországban még ezeket az országokat is meghaladó ez az arány, eléri a 35\%-ot. (Laky 1995).

Vannak természetesen jobb helyzetben lévő vállalkozások is, amelyek kizárólag a helyi piacra termelnek, de ezek tơbbsége is kisvállalkozás. Nem is foglalkoznak az exportálás gondolatával. E vállalkozások körében nem alakul ki a tơkekoncentráció folyamata, nem fejlődnek kőzép-, vagy nagyvállalatokká. Budapesten végzett vizsgálataink azt az érdekes eredményt hozták, hogy e "kisvállalatiságot" nemcsak a kényszer szüli, de a vállalkozók egy része tudatosan nem is tơrekszik többre. $\mathrm{E}$ szervezetek körében jelentős a fluktuáció.

$\mathrm{Az}$ adott helyzet és a vállalkozók mentalitása következtében negatív viszonyulás alakul ki a technológiai értékeket illetően. Más empirikus vizsgálatok azt jelezték (Makó-Ellingstad-Kuczi 1997), hogy a többségében kis-és kőzépméretü magyar zöldmezős vállalatokban igen lassan változik a technológia, a termékskála és a termelési folyamat. Részben a periférikus fejlődés modelljéböl következően, részben sajátos visszahatásként a korábbi időszak ipari szervezeti túlközpontosítására, ma e szervezettípus a leggyakoribb a hazai cégek között. (Tamás 1995). 


\section{Regionális hálózatokba kapcsolódott vállalatok: ipari körzetek}

A többnyire kézmüves gyökerủ kisméretú, gyakran családi vállalkozások hálózatai szinte teljesen hiányoznak a magyar iparban. Mindemellett már itt is megjelentek az ipari körzetek elöképei, csírái. (Ilyen tapasztalatokról számol be például, egy Budapest környéki faluban végzett vizsgálat, ahol azonos szakmájú helyi lakosok, közel húsz ácsmester, ahelyett, hogy versenyeznének egymással, inkább egyứttmüködve, együtt vállalnak rendszeresen munkảt a fövárosban. (Kuczi 1993).

\section{A high-tech hálózatokba kapcsolódott cégek: technológiai övezetek}

Ilyen szervezödésre néhány példa akad a magyar iparban, leginkább a gazdaságilag dinamikus budapesti agglomerációba, illetve az osztrák határ és a föváros közötti térségben. Igen szemléletes példa erre a Székesfehérváron fejlödö ipar. Magyarországon, Budapest után ide áramlik a legtöbb külföldi mükődőtőke. Itt nyitott gyárakat, telephelyeket az ALCOA, az IBM, a Bericap, az Emerson Electric, a Fisher Rosemount, a Texas Instruments, a Kenwood, a Ford, a Nokia, a Philips, a Parmalat, a Stollwerck, a Lorangera Shell Gas, és a Denso.

Több kutatás foglalkozott (Barta-Poszmik-Králik 1997; Ellingstad-Kuczi 1997), a Székesfehérváron müködő vállalatok kapcsolati rendszereivel, részvételükkel a térbeli munkamegosztásban. Az esettanulmányok néhány tapasztalatát összegezzuik az alábbiakban.

A régebben múkỏdỏ vállalatok sokkal inkább igyekeztek megörizni a nyersanyagot, energiát, félkész-termékeket szállítók körét, pontosabban azok származási helyét (hiszen a környező országok, vagy más magyar térségek beszállítói is átmentek a rendszerváltozás okozta vállalati átalakuláson), mint a termékeik, szolgáltatásaik értékesítésének térségét, településeit. Ez a térség vállalattól, ágazattól fưggően - igen kiterjedt, a nyersanyagok nagy része KeletEurópából és a FÁK országaiból származik. A magyar beszállítók telephelyei is többnyire Székesfehérvár, illetve régiója határain túl találhatók, bár a szállítási költségek ma már a telephelyválasztás meghatározó elemeként jönnek számításba.

Jelentős a kulönnbség a kullfóldi és a hazai vállalatok beszállítói térségeit illetően. A magyar cégek sokkal nagyobb arányban használnak a régióból, illetve Magyarországról származó inputokat, mint a külfơldi vállalatok. Ezen kívül jellegzetes különbségek mutatkoztak a zöldmezős és a privatizált vállalatok között is. (1. táblázat)

A felmérés egyértelmủen azt bizonyította, hogy a hosszú ideje müködö privatizált cégek inputjaik nagyobb részét szerzik be a régióból, és fóként Magyarországról, mint az új zöldmezős cégek. Az is érthetö, hogy a külföldi vállalkozások inputjainak nagyobb része származik külfolddơl (fóként az EU országaiból), mint a hazai vállalatoké. Mindez azt bizonyítja, hogy a vállalatok közötti kapcsolatok kiépüléséhez hosszú idöre van szulkség, a partnerek kiválasztása a helyismerettöl, és a kialakult bizalomtól, ismertségtól is függ. 


\section{TÁBLÁZAT}

Termelési inputok megoszlása származási hely szerint (\%) 1997-ben

(Spatial Sructure of Inputs of Industrial Enterprises in Székesfehérvár, 1997, \%)

\begin{tabular}{|l|c|c|c|c|}
\hline & Régió & Magyarország & EU & EU-n kívül \\
\hline Hazai zöldmezös cégek & 30,3 & 29,2 & 13,8 & 4,4 \\
\hline Hazai privatizált cégek & 27,2 & 50,3 & 15,1 & 4,9 \\
\hline Összesen & 27,8 & 46,4 & 14,8 & 4,8 \\
\hline Külfóldi zöldmezós cégek & 7,1 & 15,1 & 63,5 & 14,5 \\
\hline Külfóldi privatizált cégek & 22,5 & 54,3 & 20,8 & 2,5 \\
\hline Összesen & 9,3 & 21,8 & 54,9 & 14,0 \\
\hline
\end{tabular}

Forrás: Makó-Ellingstad-Kuczi: REGIS Székesfehérvár Region, Survey Results and Interpretation, MTA Társadalmi Konfliktuskutató Központ, 1997. 8. o.

A különbség itt is szembeszökö (2. táblázat). A magyar cégek sokkal nagyobb arányban értékesítenek a régión belül, illetve Magyarországon, mint a külfóldi vállalatok. Ugyanez a különbség megjelenik a külföldi tulajdonú zöldmezös és privatizált vállalatok között is. A magyarázat hasonló a termék inputok térségi megoszlásához, vagyis a vállalatközi kapcsolatok kialakulása és változása időigényes. A kullfơldi, és föleg a.jogelőd nélkưli kủllföldi vállalatok még lazán kapcsolódnak a térség gazdaságához.

\section{TÁBLÁZAT}

Termék kibocsátás megoszlásának területi irányai 1997-ben (\%)

(Spatial Distribution of Outputs, 1997,\%)

\begin{tabular}{|l|c|c|c|c|}
\hline & Régió & Magyarország & EU & EU-n kívül \\
\hline Hazai zöldmezós cégek & 58,1 & 37,5 & 3,8 & 0,6 \\
\hline Hazai privatizált cégek & 43,4 & 38,9 & 11,0 & 6,8 \\
\hline Összesen & 45,8 & 38,7 & 9,8 & 5,8 \\
\hline Külfỏldi zöldmezős cégek & 15,7 & 22,8 & 49,6 & 12,0 \\
\hline Külfóldi privatizált cégek & 30,0 & 47,3 & 16,3 & 6,5 \\
\hline Összesen & 16,7 & 25,0 & 43,7 & 10,8 \\
\hline
\end{tabular}

Forrás: Makó.-Ellingstad M.-Kuczi: REGIS Székesfehérvár Region, Survey Results and Interpretation, MTA Társadalmi Konfliktuskutató Központ, 1997. 8. o.

A vállalati kapcsolati rendszernek, a vállalatok között kiépülő és sokasodó kapcsolatokuak nagy jelentősége van a térség gazdasági fejlödésében. A kapcsolatok révén szervesủlnek a betelepült külföldi vállalkozások a hazai gazdaságba, e kapcsolatok révén találkoznak a különböző termelési kultúrák, ez jelent húzóerőt az alacsonyabb technológiai szinten lévő vállalatok felzárkózásához. Mondhatjuk, hogy a külfơldi múködő tóke egyik fontos szerepe éppen ez lenne a fogadó ország gazdaságában.

A székesfehérvári ipari körzet közel sem zárt terület, elsősorban Budapesthez és a budapesti agglomerációhoz füződó kapcsolatai szorosak. Budapest közelsége minden valószínűség szerint - több előnyt jelent a székesfehérvári régiónak, mint hátrányt. Budapest nem szivja el e térség erőforrásait, viszont az idetelepülö külföldi tỏke számára fontos Budapest közelsége. Budapest és agglomerációja sok 
esetben piacot jelent a székesfehérvári vállalatoknak. Hozzá kell tenni, hogy a térbeli munkamegosztás most sem kiegyenlített, Székesfehérvárott még nincsenek meg a termelés bizonyos minöségi elemei, például kívánni valókat hagy a helyi felsöfokú oktatás hiányos szerkezete és színvonala, hiányoznak a kutatás-fejlesztés intézményei, a legképzettebb munkaerő, a döntéshozók egy része még Budapeströl ingázik e térségbe.

\section{Az új munkamegosztás elsõ vonalába bekapcsolódott magyar cégek}

A munkamegosztásban eltérő szerepeket töltenek be a magyar cégek, e szerepek közül a talán négy legjellemzőbbet mutatjuk be példáinkban:

- A gyengébb minőségủ magyar termékek termelése a fejlett országok piacaira, ahol e termékek elöállítása kưlönbőzző okok miatt csökkent, vagy megszünt;

- A kelet-európai - a volt KGST - piac visszahódítása;

- Alvállalkozás-beszállitás a Magyarországon müködö, föleg nagyobb kưlföldi vállalatok számára;

- A kïlfoóldi vállalatok számára végzett bérmunka elterjedése.

Az elsó szerepre talán a magyar acélipar a legjobb példa. Magyarországon (mindez jellemzó a kelet-európai volt szocialista országokra is) az acélipar müszaki fejlesztése rregkésett és csak részleges volt. Az olcsó munkaerö, a csökkenö, de még mindig jelentős állami támogatás miatt a magyar acéltermékek ára ma is alacsonyabb a világpiaci szintnél, így a költséges elöállítás, és az elavult technológia ellenére is jelentős exportot bonyolítanak le a magyar acélmüvek. (A technológiai elavulás jellemzöje, hogy Magyarországon jelenleg a konverteres eljárás aránya a legmagasabb: 1992-ben 87\%, 1996-ban 95\% fólötti volt az aránya. Míg a fejlett európai országokban már az 1980-as évtizedben megszuntették ezt a technológiát, nálunk 1990-ben $42 \%$ volt az így elóallított acéltermékek aránya.) (Barta-Poszmik 1997) Mindemellett tartós tendenciának látszik, hogy a fejlett országok váltak a magyar acélkivitel fö piacaivá, az EU-n belül Németország és Olaszország. (3. táblázat) Egyre nagyobb erófeszítés nyilvánul meg a magyar iparvállalatok körében, hogy visszaszerezzék a rendszerváltozás során elvesztett volt kelet-európai piacaikat.

\section{TÁBLÁZAT}

A magyar vas- és acélkivitel megoszlása a célországok között 1992-1995 (\%)

(Spatial Distribution of the Hungarian Iron and Steel Export, 1992-1995)

\begin{tabular}{|c|c|c|c|c|}
\hline Országok & 1992 & 1993 & 1994 & 1995 \\
\hline Átalakuló és nem piacgazdaságú országok & 17,0 & 23,8 & 7,6 & 10,6 \\
\hline Ebból: a kelet-európal országok & 14,0 & 7,1 & 5,0 & $\mathbf{8 , 0}$ \\
\hline Piacgazdaságot folytató országok & 83,0 & 74,9 & 90,3 & 87,2 \\
\hline Fejleut országok & 62,9 & 50,1 & 75,9 & 76,3 \\
\hline Ebbỏl: EU & 44,8 & 31,4 & 57,9 & 69,4 \\
\hline EFTA & 9,1 & 6,5 & 5,8 & 0,5 \\
\hline Európán kívüli országok & 5,5 & 8,3 & 11,6 & 4,0 \\
\hline Fejiő́dó országok & 20,0 & 24,8 & 14,4 & 10,9 \\
\hline Egyéb & 0,0 & 1,3 & 2,1 & 2,2 \\
\hline Osszesen & 100,0 & 100,0 & 100,0 & 100,0 \\
\hline
\end{tabular}

Forrás: Kulkereskedelmi Statisztikai Évkönyv, 1992, 1993, 1994, 1995 
A nyugatinál sokkal szerényebb mértékben, de megindult a magyar müködő tőke befektetetés a kelet-európai országok gazdaságába. Ez idáig mintegy 0,5 Mrd USD müködő tőkét vittek ki Magyarországról. A magyar tőkekivitel 30-35\%-a a keleteurópai országokba, fơleg Romániába és Szlovákiába irányult, harmada a volt Szovjetunió területére, elsösorban Ukrajnába és Oroszországba, a fennmaradó harmad a fejlett ipari országokba került. A Magyar Hitelbank többségi tulajdont szerzett a csehországi Interbankban, amely egyelöre kivételes eset a magyar bankrendszerben. A kưlföldre irányuló magyar beruházások tőbbsége a kereskedelmet célozta meg. Valószinüusíthetö, hogy Magyarország valt a keleteurópai térség legjelentősebb tởke exportáló országává (Matolcsy 1997).

$\mathrm{Az}$ ipar teruletén jelentősebb beruházás füzödik a MOL-hoz, a gyógyszeripar, a buszgyártás, stb. teruletén összeszerelő munkák és bérmunka-kihelyezés formájában, általában azonban a nagyszámú, de esetenként kis beruházások jellemzik a magyar tökekivitelt. A magyar gyógyszeripar az elmúlt politikai rendszerben a KGST legjelentósebb gyógyszerellátója volt. A rendszerváltozást követỏ gazdasági krízis miatt a FÁK országai és a többi kelet-európai ország radikálisan csőkkenteni kényszerult gyógyszerimportját. A helyzet 1997-ben lassú változást mutatott, a kelet-európai országok gazdasága lassan konszolidálódik, a társadalombiztosítási rendszerek müködőképesek, és van fizetőképes kereslet is. A régióban azonban erös verseny, ill. piacvédelem alakult ki. Úgy tủnik, hogy a magyar termékek számára a piacnyerés leghatékonyabb módja a Kelet-Európában múkő̉ỏ termelővállalatok felvásárlása, vagy létesítése lehet.

A szovjet utódkőztársaságokban más a helyzet: nem, vagy alig mükődik a társadalombiztosítási rendszer, igy eladni csak a helyi piacokon kifejtett kemény marketingmunkával lehet. Mindemellett a legnagyobb magyar exportőrők - a Richter, a Chinoin és az Egis - már visszaszerezték korábbi pozícióikat. De az erősődő piacvédelmi intézkedések miatt további piacnyerést csak azok a magyar cégek tudnak elérni, amelyek helyi termelöüzemeket is létrehoznak. Az első ilyen uzemet a Richter nyitotta meg 1997-ben Oroszországban. (Antalóczy 1997)

A hazai beszállítói-alvállalkozói rendszer lassan épúl ki, a kapcsolatépités időigényes folyamat. A letelepülő külfőldi vállalatok nehezen találnak magyar beszállítókat, igen sok esetben a hazai kis-és középvállalatok múszaki felkészultsége nem felel meg a Magyarországon múködő külfoòldi nagyvállalatok, multinacionális vállalatok minöségi kővetelményeinek.

Sokat emlegetett példa a Suzuki esete hazánkban. A Magyar Suzuki, a legnagyobb kủlfơldi beruházások egyike, érdekelt abban, hogy megpróbáljon kooperálni a magyar iparral. Az autóexportra vonatkozó nemzetközi megállapodások szerint ugyanis a japán Suzuki csak akkor bỏvítheti eladásait a nyugat-európai piacon, ha termékében legalább $60 \%$ a Magyarországon, illetve Európában elóallított részarány. Mintegy 400 magyar vállalkozó jelentkezett a Suzuki felhívására, amikor a gyár beszállítókat keresett. A szigorú megmérettetésnek azonban csak 34-en feleltek meg. Az eddigi tapasztalatok azt mutatják, hogy ha csikorogva is, de müködik a japán-magyar egyưtttuluködési rendszer. Söt, azáltal, hogy a magyar beszállítóknak is vannak beszállítói, a japánok magas minöségi kővetelményrendszere továbbterjed a magyar ipar más területeire is. A hálózat kiépült, amelyet a japánok sem bővíteni, sem lényegesen meg változtatni nem szándékoznak. 
A beszállitó́i kapcsolatokról általában meglehetősen kevés információval rendelkezünk. A vállalatok költségszerkezetére vonatkozó adatok azt jelzik, hogy az anyagköltségen belül az alvállalkozói költségek emelkedő tendenciát mutatnak. Kullőnbơző állami és magán szervezetek foglalkoznak a beszállítók támogatásával, minöségi fejlesztésével, partnerközvetítéssel.

A bérmunka már megjelent a magyar vállalatokban a rendszerváltozás elött, jobbára a gazdasági reformnak köszönhetően. Kétségtelen, hogy a bérmunkában elöállított termékek utáni profit szerényebb, mint a márkanévvel megjelenö termékek esetében. A világszínvonalon termelö multinacionális vállalatoknak, vagy más jelentős kủföldi partnernek végzett bérmunka nemcsak elfogadható nyereséget jelent a bérmunkát vállaló vállalatnak, de biztosítja a magas technológiai színvonal elérését is. (A székesfehérvári Videoton például a Nokiával, Ericssonnal, az Eltekkel, Alcatellel, Samsunggal stb. épitett ki bérmunka jellegủ kapcsolatokat).

E szektor jelentősége növekszik a magyar exportban: 1995-ben a teljes ipari export 30,1\%-a bérmunka volt, ezen belưl a könnyüipari export $64,7 \%$-át, a konfekcióipari export 95\%-át, a cipögyártás 97\%-át adta 1995-ben. (Cseh 1997) (4. táblázat)

\section{TÁBLÁZAT}

A bérmunka-export ágazati változásai (Sectoral Changes in the Export of Commission Work)

\begin{tabular}{|l|r|r|r|r|}
\hline \multicolumn{1}{|c|}{ Ágazat } & \multicolumn{1}{|c|}{1991} & 1991 & 1995 & 1995 \\
\hline & $\begin{array}{c}\text { Ǒsszes } \\
\text { export } \\
\text { M USD }\end{array}$ & $\begin{array}{c}\text { Bérmunka-export } \\
\text { részarány (\%) }\end{array}$ & $\begin{array}{c}\text { Összes export } \\
\text { M USD }\end{array}$ & $\begin{array}{c}\text { Bérmunka-export } \\
\text { részarány (\%) }\end{array}$ \\
\hline Bányászat & 16 & 0 & 13 & 7,7 \\
\hline $\begin{array}{l}\text { Villamosenergia- } \\
\text { ipar }\end{array}$ & - & - & 5 & - \\
\hline Kohászat & 910 & 5,9 & 1142 & 14,4 \\
\hline Gépipar & 2566 & 18,1 & 3889 & 28,5 \\
\hline Építóipar & 21 & 0 & 13 & 7,7 \\
\hline Építőanyagipar & 217 & 0 & 236 & 0,8 \\
\hline Vegyipar & 1775 & 19,0 & 2191 & 9,1 \\
\hline Könnyüipar & 1672 & 52,7 & 2285 & 64,7 \\
\hline Egyéb ipar & 52 & 13,5 & 82 & 20,7 \\
\hline Ipar összesen & 7229 & 24,1 & 9856 & 30,1 \\
\hline Külkeresk. & 9972 & 17,9 & 12861 & 24,1 \\
\hline
\end{tabular}

Forrás: Ipari és Keresk. Minisztérium éves jelentései a bérmunkáról (Cseh 1997, 21 o.)

A bérmunka mentette meg a ruházati ipart Magyarországon, és általában, a bérmunka elfogadható túlélési stratégiának. Az a haszna máris jelentkezett - a munkahelyek megmentésén és a jövedelmezö gazdálkodáson túl - hogy egy sor korábbi bérmunkáltató vállalatot alapított Magyarországon (például a Levi Strauss, az angol Elit Group, vagy a német Baumler és Rosner cégek). De a bérmunkából nagyon nehéz a ki- és továbblépés. A bérmunkát végző cégek elkényelmesednek, elfelejtik az ơnálló fejlesztést, másrészt nem tudnak elég tơkét felhalmozni a fejlesztéshez. Gyakran kulső segítségre van szüksége a bérmunkát végzỏ cégeknek, hogy őnálló vállalkozásba legyenek képesek kezdeni (ebben segít a PHARE program, vagy a Magyar Befektetési és Kereskedelemfejlesztési Rt - ITD Hungary). 


\section{Kutatás és fejlesztés $(K+F)$}

A tervgazdasági rendszerben viszonylag kiterjedt kutatóintézet hálózat múködőtt, amely azonban meglehetősen lazán kapcsolódott a gazdasághoz, és így igen kishatékonyságú volt. Az innováció és a $\mathrm{K}+\mathrm{F}$ tevékenység részben minisztériumi kutatóintézetek, részben a Magyar Tudományos Akadémia intézeteinek feladata volt. A régi rendszer lineáris modellre épült, amely az állam innovációs politikájához kapcsolódott. Az állam finanszírozta a $\mathrm{K}+\mathrm{F}$ tevékenységet és a közoktatást. És így bár a tervgazdasági rendszer ezer sebből vérzett, a kutatás, fejlesztés és más innovatív tevékenység viszonylag fejlett volt. ( $M$. van Geenhuizen, 1997) (5. táblázat)

\section{TÁBLÁZAT}

$K+F$ rendszerek a tervgazdaságokban és a piacgazdaságokban

(R\&D Systems in the Centrally Planned and Market Economies)

\begin{tabular}{|c|c|c|}
\hline \multirow{6}{*}{$\begin{array}{l}\text { Müszaki } \\
\text { kinálat }\end{array}$} & & Piacgazdaság \\
\hline & - elkülơnült intézményekben & $\begin{array}{l}\text { - vállalatokban, vállalati hálózatokban, } \\
\text { más szervezetekben. } \mathrm{A} \mathrm{K}+\mathrm{F} \text { teamek } \\
\text { flexibilisek. }\end{array}$ \\
\hline & $\begin{array}{l}\text { - műszaki irányultságú, követő } \\
\text { jellegủ } \mathrm{K}+\mathrm{F}\end{array}$ & $\begin{array}{l}\text { - a technológia és a piac egyaránt } \\
\text { szerepet játszik a } K+F \text {-ben }\end{array}$ \\
\hline & - kőltség és ár érzéketlenség & - piac-orientált szolgáltatások \\
\hline & - a technológiai transzfer hiánya & $\begin{array}{l}\text { - a technológiai transzfer fontos szerepet } \\
\text { játszik (kölcsönös hatások) }\end{array}$ \\
\hline & - lineáris innovációs modell & - interaktív modell \\
\hline \multirow[t]{3}{*}{$\begin{array}{l}\text { Müszaki } \\
\text { kereslet }\end{array}$} & - a központi tervezés meghatározó & $\begin{array}{l}\text { - az elérhető technológiák és a piac } \\
\text { határozza meg }\end{array}$ \\
\hline & - kötött & - rugalmas \\
\hline & - tudományágon belüli megközelítés & - tudományágak közötti egyưtttmükődés \\
\hline
\end{tabular}

Forrás: M.Van Geenhuizen, 1997, 8. o.

A $\mathrm{K}+\mathrm{F}$ ráfordítások 1988-1993 között reálértékben a GDP csökkenésénél jóval nagyobb mértékben estek vissza, közel 54\%-kal. A $\mathrm{K}+\mathrm{F}$ ráfordítások aránya Magyarországon nemzetközi viszonylatban amúgy is igen alacsony: 1989-ben a GDP 2\%-a, 1990-ben 1,7\%-a, 1991-ben 1,2\%-a, és 1993-ban 1\%-a volt. A kutatók szåma 17.550 fỏröl 11.820 före csőkkent 1993-ra, de a létszámleépittés kényszere még nem szünt meg (a MTA intézeteiben 1998 végéig a 4000 fös kutatóállományt további $25 \%$-kal fogják csökkenteni).

A $\mathrm{K}+\mathrm{F}$ források beszükülése differenciáltan jelentkezett a különböző típusú szervezeteknél. Az ipar kutatóintézetek egy része megszünt, másik része éppen vegetál rendelés hiányában. 1988-93 között a kutatóintézeti kör árbevétele nominál értékben $82 \%$-kal csökkent. Mind a $\mathrm{K}+\mathrm{F}$ tevékenység, mind az intézményi rendszer gyökeresen átstrukturálódik. Csökkent az önálló, cégen belül elkülönült $\mathrm{K}+\mathrm{F}$ tevékenységek aránya, nótt az alkalmi megbízások száma.

Az ipari vállalatokban az 1993-94 években végzett felmérések (Tamás 1995) szerint csökkent az érdeklődés az innováció iránt, a $\mathrm{K}+\mathrm{F}$ tevékenységre egyre kevesebbet költöttek. A vállalatok csak saját erőforrásaikra támaszkodhattak ilyen jellegů tevékenységük költségeinek fedezésében. Az állam mozgástere egyre 
szủkült, a külfơldi beruházók pedig nem különösen érdekeltek a $\mathrm{K}+\mathrm{F}$ támogatásában Magyarországon. A kutatás-fejlesztés következésképpen a külföldi vállalatokban sem jelentös.

Meg kell jegyeznünk azonban, hogy mindez nem csupán finanszírozási kérdés. A vállalati menedzsment szívesebben fogadja el a külfơldi technológiákat, mint a "házon belüli" kutatások eredményeit. Ez magyarázza a know-how és a licencek növekvö importját, különösen a külföldi részesedésủ vegyes vállalatokban.

$\mathrm{A} \mathrm{K}+\mathrm{F}$ tevékenység visszaesése összefügg a vállalati méretek csőkkenésével is. A rendszerváltozás után szétesett nagyvállalatok korábban a technológiai fejlesztés központjai voltak. A kisvállalatok kevésbé innovatívak, és anyagi lehetöségeik is szerényebbek.

Nyilvánvaló, hogy az állam helyét és szerepét a technológiai fejlesztésben nem tudják átvenni a piac-orientált intézmények. Ez azonban nem jelenti azt, hogy az új állami fejlesztés-politikának ne kellene a piacgazdasághoz illeszkednie. A $\mathrm{K}+\mathrm{F}$ tevékenység megújulására, a termelés és a $K+F$ közötti hatékony kapcsolatrendszer kiépülésére Kelet-Európában azonban csak az átmeneti időszak lezárulása után lehet számítani. (Szántó 1994).

\section{Következtetések}

A magyar gazdaság szervezeti átalakulását kétpólusú ipari struktúra jellemzi (Budapest Bank 1997). Az egyik pólust a nemzetközi hálózatokba sikeresen integrálódott vállalatok és ágazatok képviselik. Ezek többsége multinacionális, vagy nagyobb méretü, külfoldi tulajdonú vállalat. Az ipari növekedés 60-70\%-a 1997-ben e vállalati csoporthoz kötỏdött. A multinacionális vállalatokhoz kapcsolódott alvállalkozói, bedolgozói hálózat kis-és középméretü vállalatai szintén fejlobdésnek indultak, föleg a személygépkocsi gyártásban, az elektronikai-, a papir- és csomagolóiparban.

A másik póluson tömörül a cégek többsége. Termelésük stagnál, vagy igen lassan növekszik, technológiai megújulásuk erösen korlátozott. Elsősorban hazai piacra termelnek. Egy másik klasszifikáció a cégeket exporttal nem foglalkozó; összeszerelö-exportáló; és export-orientált hazai vállalatokra osztja. (Éltetö-Sass 1997).

Esettanulmányok sora bizonyítja, hogy a külföldi vállalatok integrálódása a magyar gazdaságba - különösen a multinacionális vállalatoké - igen lassú folyamat. Ugyanakkor az sem állítható, hogy e külföldi vállalatok szigeteket alkotnának a magyar gazdaságban. De nem cáfolható, hogy a magyar gazdaság két pólusa (vagyis a hazai piacra termelö, hazai tulajdonú vállalatok, valamint a multinacionális vállalatok és alvállalkozóik) között a kapcsolat igen gyenge. Söt, maguk a multinacionális vállalatokhoz kapcsolódó alvállalkozók is gyakran külfóldi vállalatok. A hazai vállalatok egyelöre meglehetősen szerény szerepet játszanak az új munkamegosztásban, többnyire alacsony technológiai színvonalon, képzetlen, olcsó munkaerővel végeznek feldolgozóipari tevékenységet.

A fent leírt, általános folyamatok határozzák meg a technológiai szintet a mai magyar gazdaságban. Nem kétséges, hogy a külföldi vállalatok megjelenése, és egyre jelentősebb részvételük a termelésben ösztönző hatású a magyar gazdaságra. 
A gazdasági nővekedés és az export expanzió jobbára e vállalatcsoport tevékenységének kőszönhetỏ. Technológiai fejlettségük, ha nem is világszínvonalú, de mindenképpen meghaladja a magyar átlagot. Sajnos, ez a magasabb, de nem élvonalbelinek számitó müszaki szinvonal is igen lassan terjed a magyar gazđaságban. Tehát a kủlföldi vállalatok ugyan a magyar gazdaság "motorjának" szerepét töltik be, fejlettebb technológiájuk diffúziója gyenge, amely a magyar gazdaságba való lassú integrálódásuknak tulajdonitható.

\section{Jegyzetek}

1 A magyar ipar szempontjából fontos és kedvezỏ hatása van a multinacionális vállalatok beruházásainak. 1995-ben a világ 50 legnagyobb iparvállalata kơzul 35 már megjelent a magyar gazdaságban, és az osszes kulföldi múködőtőke kozel 20\%-a volt zőldmezős beruházás (a multinacionális, illetve nemzetkozi nagyvállalatok kőzul 100 millió dollárnál tobbet invesztált a magyar gazdaságba a General Electric, a General Motors, az Audi, a Ford, a Philips, az Unilever, a Sanofi, a Suzuki, a Siemens, a Guardian Glass, a Prinzhorn csoport, a Sare Lee és a Feruzzi. A zóldmezós beruházásokból a gépipar kőzel kétharmad arányban részesedett. Kiemelkedő fontosságú az autóiparba fektetett tőke, amely az ósszes FDI kb. 10\%-át teszi ki. A másik jelentós alágazat az elektronikai ipar, ahol a Philips beruházásai meghatározóak (Diczházi 1995).

2 A magyar ipar szempontjából fontos és kedvezỏ hatása van a multinacionális vállalatok beruházásainak. 1995-ben a világ 50 legnagyobb iparvállalata kơzul 35 már megjelent a magyar gazdaságban, és az ósszes kulfoldi múkơdótöke kozell 20\%-a volt zolldmezős beruházás (a multinacionális, illetve nemzetkơzi nagyvállalatok kőzul 100 millió dollámál tơbbet invesztált a magyar gazdaságba a General Electric, a General Motors, az Audi, a Ford, a Philips, az Unilever, a Sanofi, a Suzuki, a Siemens, a Guardian Glass, a Prinzhorn csoport, a Sare Lee és a Feruzzi. A zơldmezős beruházásokból a gépipar közel kétharmad arányban részesedett. Kiemelkedö fontosságú az autóiparba fektetett tóke, amely az osszes FDI kb. 10\%-át teszi ki. A másik jelentős alágazat az elektronikai ipar, ahol a Philips beruházásai meghatározóak (Diczházi 1995).

\section{Irodalom}

Antalóczy K. (1997) A magyar gyógyszeripar versenyképessége. Mühelytanulmányok, 17. Budapesti Kózgazdaságtudományi Egyetem, Vállalatgazdaságtan Tanszék. 51. o.

Barta Gy. (1994) Foreign investment in the Hungarian economy: the role of transnational companies pp. 131-151. (In: P. Dicken and M. Quévit (eds.) Transnational corporations and European regional restructuring) Netherlands Geographical Studies 181 . Utrecht.

Barta Gy. - Králik M. - Perger E. (1997) Achievements and conflicts of modernization in Hungary. European Spatial Research and Policy, Vol. 4. No. 2. University of Lodz, University of Groningen, University of Bratislava, University of the West of England, Bristol, 61-82. o.

Barta Gy. - Poszmik E. (1997) A vas-és acélipar versenyképességét befolyásoló tényezök. Mühelytanulmányok, 15. Budapesti Kỏzgazdaságtudományi Egyetem, Vállalatgazdaságtan Tanszék. 73. 0.

Barta Gy. (1997) Ipari nagyvállalatok Fejér megyében. MTA RKK, Budapest, 24. o.

Csáki Gy. - Sass M. - Szalavetz A. (1996) Reinforcing the modernization role of foreign direct investment in Hungary Working Papers No.62. Institute for World Economics, Hungarian Academy of Sciences, Budapest. 37. o.

Cseh J. (1997) A magyar textil- és textilruházati ipar helyzete, a versenyképességét meghatározó tényezök. Mưhelytanulmányok, 13. Budapesti Közgazdaságtudományi Egyetem, Vállalatgazdaságtan Tanszék. 76. o.

Diczházi B. (1996) Kulfơldi beruházások Magyarországon 1995 végéig. Kulföldi, zöldmezős ipari beruházások Magyarországon. Tulajdon Alapitvány, Privatizációs Kutatóintézet, Budapest, 100. 
Van Geenhuizen M. (1997) Opportunities for innovation in Central and Eastern Europe: The role of foreign Direct Investment. Paper for the RSA Nederland Dag 1997 "Innovatie in bedrijf en regio: strategie en praktijk". April $11^{\text {th }} 1997$, Utrecht.

Grayson L. E. - Bodily S. E. (1996) Integration into the world economy: companies in transition in the Czech Republic, Slovakia, and Hungary (IIASA, Laxenburg).

Kuczi T. (1993) Collective Work Organization of Small Firms in Hungary. Conference on the Social Embeddedness of the Economic Transformation in Central and Eastem Europe. Social Science Research Center Berlin (WZB) Sept. 24-25, 1993. 21. o.

Laky T. (1995) A magángazdaság kialakulása és a foglalkoztatottság. Közgazdasági Szemle, 7-8. 685-709. o.

Makó Cs. - Ellingstad M. - Kuczi T. (1997) REGIS. Székesfehérvár region -Survey results and interpretation. Center for Social Conflict Research, Hungarian Academy of Sciences. Budapest, 35. o.

Matolcsy Gy. (1997) A budapesti régió lehetséges szerepe a regionális együttmükődésben. Tulajdon Alapitvány, Privatizációs Kutatóintézet, Budapest, 111. o.

Szántó B. (1994) Innovation in crisis: Hungary before and after the watershed of 1989. Technovation, Vol. 14, 601-611. o.

Tamás P. (1995) Innovációs folyamatok a magyar gazdaságban. Országos Mủszaki Fejlesztési Bizottság, Budapest

Középtávú iparpolitika az ipar versenyképességének növeléséért. Ipari és Kereskedelmi Minisztérium (911/795/1995) Budapest, 1995. december.

Makrogazdasági elemzések, prognózis 1997-re. Budapest Bank Rt., 1997 március

"TOP 200" A legnagyobb magyar vállalatok, 1997. Figyelö, melléklet 